\title{
Understanding Purchase Intention of Youth towards Cause Related Marketing
}

\author{
Jha Suchita
}

\begin{abstract}
Originality/Research need:Transformation is the key for the success of any business today. The marketing function cannot be an exception and we see the adoption of a new trends in the integrated marketing communication space. Cause Related Marketing (CRM) is one such methodology which gives a chance to do something for society. This gives marketers a choice for connecting and engaging with consumers at their convenience since cause related marketing gives satisfaction to consumer, makes it fascinating and also enhances brand engagement. Limited research has been done in the area of cause related marketing and what factors influence the purchase intention

Objective of the study: Hence the objective of this study is to determine the factors which influence the purchase intention towards cause related marketing products.

Methodology: The researcher has used quantitative research methodology for this study. A structured questionnaire was circulated to the experimental group in order to gather their opinion and was the source of primary data for the analysis. Data analysis was done using statistical methods.

Implications of the study: The study will prove helpful to academicians, managers and for companies by providing insights into the impact of using cause related marketing for advertising or marketing communication purpose.
\end{abstract}

Key words: Brand Attractiveness, Cause Related Marketing, Consumer purchase intention

\section{INTRODUCTION:}

In this competitive market to position your product differently cause-related marketing has come out as a way for marketers (Marín and Ruiz, 2007). As stated by (Adkin, 2004) the strategic alliances of brand always give a prominence to the brand presence. $\mathrm{T}$

The public has gradually expected large corporations a nd small businesses to donate to nonprofit causes

(Davidson, 1994).

In the Indian sense, marketers ' social responsibility has bee $n$ discussed many times. To enhance the well-being of consumer and society societal marketing determines the need wants and interest of target group. (Kotler, 2011). Modern marketing strategies are represented by cause-relat ed marketing (Taylor 2007).As observed in work by (chattananon et al. 2008) that most of the companies are doing cause-related marketing ( Till and Nowak 2000) to build a positive brand image. Companies must balance their revenue, public interest and consumer satisfaction in order to have real impact. Therefor

Revised Manuscript Received on March 2, 2020.

* Correspondence Author

Suchita Jha, Assistant Professor, Symbiosis Institute of International Business, Symbiosis International (Deemed University), Hinjewadi, Pune, Maharashtra, India. Email: suchita.jha@siib.ac.in. e, it began to further understand this advertising relevant to the cause

Studies in many parts of the world shows that causal marke ting (CRM) results in the company's improved monetary pr ofit. (Adkin 2000: Kotler \& Kelly 2006)

Cause-related marketing firms also accomplish non-mo netary marketing targets such as "growing corporate credibi lity, raising brand awareness, increasing customer loyalty, b uilding sales, and increasing press coverage."Out of the total population of 1.25 million in India, young consumers comprise $65 \%$ of the total population in India.

(Euromonitor,2015) And been observed that $75 \%$ of Indian youth spends $6000 \mathrm{INR}$ (p.m) towards purchases of consumer goods and services. These Young group also influences family buying decisions. The spent on Cause sponsorship is predicted to reach $\$ 2.78$ billion in 2017 in India, so this marketing effort seems to have good potential. That is the reason the present study is inclined to study the youth and the variables which affect their purchase intention - the survey by Shabbir, S., Kaufmann, H. R., Ahmad, I., \& Qureshi, I. M. (2010). Shows that there are various reasons which influence the purchase intention of youth like the cause association, brand and the role of gender and profession and the present study tries to identify the correlation in the Indian context. The various research been done with the impact of gender and taking attitudinal behaviour factor or perception control variable as a construct of study but none of the surveys looked into brand reliability $\&$ its effect on purchase intention. The present study tries to look at the impact of brand reliability, gender \& social cause as an independent variable affecting the dependent variable that is purchase intention towards cause-related marketing products.

\section{RESEARCH CONSTRUCTS:}

For this research Purchase Intention has been identified as the dependent variable and gender, social cause and brand reliability been taken as independent variable for the given study .

\subsubsection{Gender :}

It is argued that the consumption behaviour of consumers towards cause-related marketing is influencing gender. Women and men are different in their values, attitudes, and practices towards consumption. Women have more empathetic feelings as compared to men, and there is a link between empathetic feelings and the will to contribute to society. (Meijer and Schut, 2005). So women tend to behave more prosaically and thus likely to respond positively towards the cause-related marketing products or campaigns. This affects the

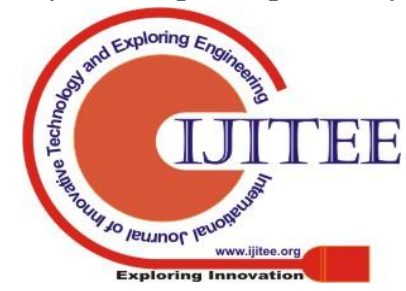


firm and the product which is asking for a share to promote the social cause.

Lot of reserachers have undertaken to determine the factors and characteristics of consumers who are very likely to respond positively to cause-related marketing (Bennett, 2009; Bloom et al., 2006). Socio demographic attributes like education, gender, age, and the income generated contradictory findings. Every factor affects the purchase intention of consumers either positively or negatively. Women are more empathetic and hence are judged as an excellent contributor to cause-related marketing. (Bennett, 2009; Bloom et al., 2006). The study argues that along with gender factors like empathy, and charitable behaviour will show a positive response to cause-related marketing.

Proposition 1: Gender significantly affects consumer purchase intention towards cause related marketing products

\subsubsection{Social Cause :}

An attribution to social cause as per the theory influences people's behaviour to respond towards cause-related products. The social object is defined regarding the prosocial behaviour which is carried out to benefit the other person without the anticipation of personal gain (Dahl \& Lavack,1995). This suggests that there are explanations for prosocial behaviour and the impact of it on the purchase of cause-related products. People support causes relating to disaster relief . (Ross et al., 1990-1991 Individuals are easier to connect with a cause pr oposal with selfinterest motives. In general, the local divisio $\mathrm{n}$ of a national charity addresses local issues and may benefi t local people or communities (Kim \& Johnson, 2013).

Ross, J.K., Stutts, M.A. and Patterson, L.T. (1990-1991), According to the report, people are more likely to support $r$ egional-focused causes than national ones.Other

categorization of support is whether it is transaction-based or non-transaction-based.

In marketing related to transaction-based causes, the compa ny's donation is based on consumer sales. It may also take $\mathrm{t}$ he form of dollar support, percentage support, or product su pport; consumers feel that an affinity for a social cause appe ars to be a moderator of cause-related activities.

Proposition 2: Social cause significantly affects consumer purchase intention towards cause related marketing products

\subsubsection{Brand reliability}

Refers brands promise to customer that how product will perform, in a specific time frame. Three critical components that appear to be essential for purchase intention and brand reliability are brand image, quality of the merchandise/brands sold and price/promotions. Lafferty et al., 2004, noticed that consumer responses towards cause-related marketing, their perceptions, and attitudes towards the company/brand/product is strongly influnced by barnd trust or relibility. "In the context of a CRM campaign, brand credibility could be described as the degree to which a customer perceives th e brand as expressing honesty and trustworthiness and poss essing the skills and experience necessary to identify with $\mathrm{t}$ he specific social cause" (Bigné-Alcañiz, E., Currás-Pérez, R., \& Sánchez-García,2009). As discussed by (Lafferty et al., 2004; Trimble and Rifon, 2006; Barone et al., 2007) there are two general ways of operationalizing brand reliability, one is on the basis of functional fit and the other based on image fit. The functional fit is determined by the functions of category association of the brand, and the type of cause it is associated with (e.g., cosmetics products and environmental conservation). Image fit, Nonetheless, it is dependent on the presence of positioning characteristics between the brand and the consumer; thus, c onsumers ultimately determine the type of fit by contrasting their brand image with the image of the particular cause.

In their paper Forehand and Grier (2003), Consumer feel a disconnect and avoids the brand if the brand focuses on ego and on other hand talk about social cause. Understanding what the brand it is trying to convey and its real motives is crucial, this will inhibit the brand's possible sense of deception and exploitation. Thus, the study shows that brand trust and reliability is an indicator which helps individuals to determine whether to buy a cause-related product or not. The association of a theme product gives a positive understa nding of customer attitudes towards business (Boucher et al. , 1994; Kirmani and Campbell, 2000; Ellen et al., 2000). S upported a related idea, indicating that consumers prefer alt ruistic-motivated products to income.

Proposition 3: Brand reliability significantly affects consumer purchase intention towards cause related marketing products

\section{RESEARCH METHOD:}

The paper takes a quantitative approach to arrive at a co nceptual model based on assessment and survey analysis. $\mathrm{T}$ he data for this study was collected via question-pro online questionnaire domain. The data are analysed for relevance from perspective of the three factors . The present study is restricted to millennials because millennial are the largest and most influential generation of consumers in India. They are the major purchase group and they want to give back to society and they usually spend approximately $\$ 600$ billion annually. Although definitions of Millennial vary, but it is typically accepted that the term refers to a category of consumers born between 1980 and 2000, Forbes defines Millennial as consumers aged between 20 and 35 .

Since the survey required the cause related marketing data hence convenience sampling was adopted and the sample population. About 156 volunteered for the same and were asked to fill in the structured questionnaire. The collected data was analyzed using factor and regression analysis to test the hypotheses.

\section{CONCEPTUAL MODEL:}

Based on the literature review the following conceptual model and hypotheses have been proposed. 


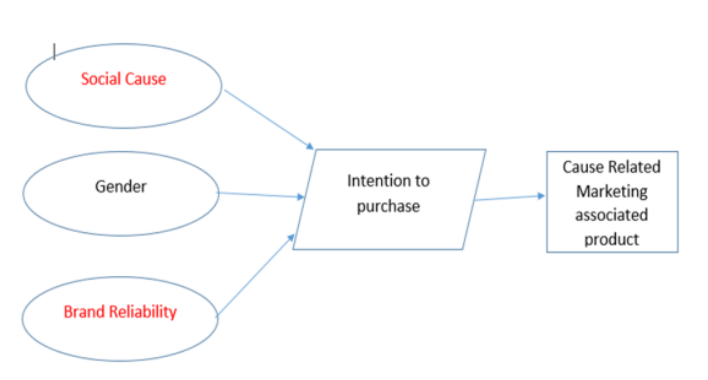

Fig 1: Conceptual model:

H1: Gender significantly affects consumer purchase intention towards cause related marketing products $\mathrm{H} 2$ : Social cause significantly affects consumer purchase intention towards cause related marketing products H3: Brand reliability significantly affects consumer purchase intention towards cause related marketing products

\section{DATA ANALYSIS AND FINDINGS:}

With the use of causerelated marketing, a Likert scale w as used to obtain customer responses to the constructs influe ncing product purchasing intention. The Cronbach Alpha test was used to determine the reliability of the scale used. The value for Cronbach Alpha which is 0.63 portraying good internal consistency.

The Kaiser-Meyer-Olkin (KMO) Test was conducted in order to measure how suitable the data was for conducting factor analysis. This test tells us the adequacy of the sample for the different variables and the model as a whole. Table 1 below showcases the results for the KMO test as 0.492 which falls between the standard ranges. (See table 1)

Table 1: KMO and Bartlett's Test

\begin{tabular}{|c|c|c|}
\hline \multicolumn{3}{|c|}{ KMO and Bartlett's Test } \\
\hline \multicolumn{2}{|c|}{ Kaiser-Meyer-Olkin Measure of Sampling Adequacy. } & .492 \\
\hline Bartlett's Test of Sphericity & Approx. Chi-Square & 1910.692 \\
\hline & df & 351 \\
\hline & Sig. & .000 \\
\hline
\end{tabular}

\subsection{Factor analysis:}

The objective of the study was to identify the constructs important for purchase intention of millennia's towards cause related marketing . Hence exploratory factor analysis was used to classify parameters affecting purchase intention. The principal component analysis with varimax rotation was used for exploratory factor analysis. $78 \%$ of the overall variance in the variables could be explained by the three factors which resulted after the factor analysis. The three factors were labelled as and gender, social cause and brand reliability. (Ref Table 2)

Table 2: Factor analysis for identified factors:

\begin{tabular}{|l|l|l|l|}
\hline & & $\begin{array}{l}\text { Rotated } \\
\text { component } \\
\text { Matrix }\end{array}$ & \\
\hline & & Component & \\
\hline & 1 & 2 & 3 \\
\hline Gen1 & 0.898
\end{tabular}

\begin{tabular}{|llll|} 
Gen2 & 0.854 & & \\
Gen3 & 0.818 & & \\
Gen4 & 0.592 & & \\
SC1 & & 0.849 & \\
Sc2 & & 0.791 & \\
Sc3 & & 0.754 & \\
BRR1 & & & 0.546 \\
BRR2 & & & 0.883 \\
BRR3 & & & 0.773 \\
BRR4 & & & 0.809 \\
\hline
\end{tabular}

\subsection{Regression Analysis:}

To identify the relationship between independent and dependent variable regression analysis was conducted. Here we took purchase intention as dependent unit and gender, social cause, brand reliability were taken as independent variables. The $\mathrm{R}$ value is 0.791 (See table 3)which tells us there's a strong relationship between purchase intention and the three factors The R square value here is .626 ((See table 3 ) which lies between 0 and 1 indicating that 62 per cent of the variation in purchase intention is accounted for through the combined linear effects of the three factors.

\section{Table 3: Model Summary}

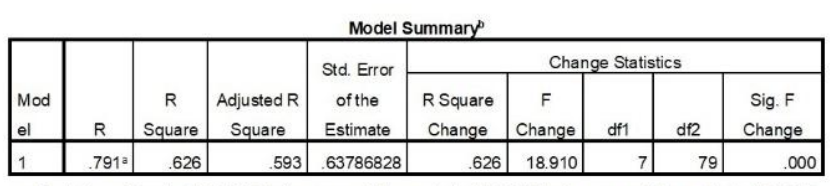

a. Predictors: (Constant), REGR factor score 5 for analysis 1 , REGR factor score 6 for analysis 1 , REGR factor score 4 for analysis 1 , REGR factor score 3 for analysis 1 , REGR factor score 2 for analysis 1 , REGR factor score 1 for analysis 1 , entertaining

b. Dependent Variable: REGR factor score 7 for analysis 1

\begin{tabular}{|c|c|c|c|c|c|}
\hline Model & Coeffiecients * & & & & \\
\hline $\begin{array}{c}\text { unstandradised } \\
\text { coeffient }\end{array}$ & B & $\begin{array}{c}\text { Standard } \\
\text { coeffient }\end{array}$ & $\mathrm{t}$ & sig \\
\hline $\begin{array}{c}\text { 1(Constant }) \\
\text { Error }\end{array}$ & -4.512 & 0.398 & Beta & & 0.000 \\
\hline $\begin{array}{c}\text { REGR factor score } \\
\text { for analysis1 }\end{array}$ & 0.685 & 0.096 & 0.685 & 7.528 & 0.000 \\
\hline $\begin{array}{c}\text { REGR factor score } \\
\text { 2 for analysis1 }\end{array}$ & -0.244 & 0.072 & -0.244 & -3.39 & 0.001 \\
\hline $\begin{array}{c}\text { REGR factor score } \\
\text { 3 for analysis2 }\end{array}$ & 0.116 & 0.07 & 0.116 & 1.668 & 0.003 \\
\hline $\begin{array}{c}\text { a. Dependent } \\
\text { variable : REGR } \\
\text { factor score 3 for } \\
\text { analysis1 }\end{array}$ & 1.1 .04 & 0.096 & 1.193 & 11.505 & 0.000 \\
\hline
\end{tabular}

Table 4: Coefficients 
In this research, as independent variables, gender, ( GEN) Social cause (SC) and Brand reliability (BRR) have been examined with purchase intention towards cause related marketing. As the Table 4 indicates the $p$ values for all the three factor is significant. The $\mathrm{P}$ value for factor 1 (gen), is .000 indicating $99 \%$ confidence in the value of the estimated coefficient. (See table 4)For factor 2 (social cause) the significance value is .001 and for factor 3 (brand relaibility) the value is .003 which is less than.05 indicating 95 percent confidence in the value of the estimated coefficient (see table 4). From this it is clear that all the factors are significantly affecting the independent variable.

\section{MANAGERIAL IMPLICATION:}

This can be valuable information for marketers towards planning the marketing programs for youth. They can also decide on the social cause based on the different demographic outlook. A marketer can get insight about CSR for a respective group of students by this study. It creates a platform for marketers to connect with youth in different ways. Marketer or HR firms can be more active on corporate philanthropy and focus on ethical issues

\section{CONCLUSION:}

This study was undertaken with the aim of determining the impact of cause related marketing on consumer purchase intention. Based on literature review 11 variable were identified which were further clubbed into 3 factors based on factor analysis. The three identified factors viz gender, social cause and brand reliability were significant and effect purchase intention towards cause related marketing products

Regression analysis was further done to test the hypotheses and results showed that all 3 factors were significant hence all 3 hypotheses stand accepted. (See table 5)

Table 5: Results of the Hypotheses Testing using regression analysis

\begin{tabular}{|l|l|l|l|}
\hline & Hypotheses & $\begin{array}{l}\text { Sig. P } \\
\text { value }\end{array}$ & Result \\
\hline $\mathbf{H 1}$ & $\begin{array}{l}\text { Gender significantly affects } \\
\text { consumer purchase intention towards } \\
\text { cause related marketing products }\end{array}$ & 0.000 & Accepted \\
\hline $\mathbf{H 2}$ & $\begin{array}{l}\text { Social cause affects consumer } \\
\text { purchase intention towards cause } \\
\text { related marketing products }\end{array}$ & 0.001 & Accepted \\
\hline $\mathbf{H 3}$ & $\begin{array}{l}\text { Brand Relaibility affects consumer } \\
\text { purchase intention towards cause } \\
\text { related marketing products }\end{array}$ & 0.003 & Accepted \\
\hline
\end{tabular}

\section{REFERENCES:}

1. Ajzen, I. (2011). Theory of planned behavior. Handb Theor Soc Psychol Vol One, 1(2011), 438

2. Barone, M.J., Miyazaki, A.D. and Taylor, K.A. (2000), "The influence of cause-related marketing on consumer choice: does one good turn deserve another?", Academy of Marketing Science Journal, Vol. 28 No. 2, p. 248

3. Berger, I.E., Cunningham, P.H., \& Kozinets, R.V. (1999). Consumer persuasion through cause-related advertising. Advances in Consumer Research, 26, 491-497.

4. Bettman, J.R. (1979), An Information Processing Theory of Consumer Choice, Addison-Wesley, Reading, MA.
5. Bhattacharya, C.B., and Sen, S. (2003), "Consumer-company identification: a framework for understanding consumers' relationships with companies," Journal of Marketing, Vol. 67, April, pp. 76-88.

6. Bigné-Alcañiz, E., Currás-Pérez, R., \& Sánchez-García, I. (2009). Brand credibility in cause-related marketing: the moderating role of consumer values. Journal of Product \& Brand Management, 18(6), 437-447.

7. Brown, T.J., and Dacin, P.A. (1997), "The company and the product: corporate associations and consumer product responses," Journal of Marketing, Vol. 61 No. 1, pp. 68-84.

8. Bucklin, L.P. and Sengupta, S. (1993), "Organizing successful co-marketing alliances," Journal of Marketing, Vol. 57 No. 2, p. 32.

9. Caesar, P. (1986). Cause-related marketing: The new face of corporate philanthropy. Business and Society Review, 15-19.

10. Demetriou, M., Papasolomou, I., \& Vrontis, D. (2010). Cause-related marketing: Building the corporate image while supporting worthwhile causes. Journal of Brand Management, 17, 266-278.

11. Dr. Mahmood M. Haijat Ph.D. JOURNAL OF NONPROFIT \& PUBLIC SECTOR MARKETING VOL. 11, ISS. 1,2003 Effect of Cause-Related Marketing on Attitudes and Purchase Intentions: The Moderating Role of Cause Involvement and Donation Size

12. Drumwright, M.E. (1996), "Company advertising with a social dimension: the role of non-economic criteria," Journal of Marketing, Vol. 60 No. 4, pp. 71-87.

13. Ellen, P.S., Mohr, L.A. and Webb, D.J. (2000), "Charitable programs and the retailer: do they mix?", Journal of Retailing, Vol. 76 No. 3, pp. 393-406.

14. Gadhavi, D.D., Shukla, Y.S., \& Patel, J.D. (2014). Moderating role of cause-related marketing campaign between attitude towards products and purchase intention: An experimental analysis. Indian Journal of Marketing, 44 (3), 35-42.

15. Hou, J., Du, L., \& Li, J. (2008). Cause's attributes influencing consumer's purchasing intention: Empirical evidence from China. Asia Pacific Journal of Marketing, 20 (4), 363-380 DOI: 10.1108/13555850810909704

16. Irwin, R.L., Lachowetz, T., Cornwell, T.B., \& Clark, J.S. (2003) Cause-related sports sponsorship: An assessment of spectator beliefs, attitudes, and behavioral intentions. Sports Marketing Quarterly, 12 (3), 131-139.

17. Kim, J. E., \& Johnson, K. K. P. (2013). The Impact of Moral Emotions on Cause-Related Marketing Campaigns: A Cross-Cultural Examination. Journal of Business Ethics. https://doi.org/10.1007/s10551-012-1233-6

18. Luk, S. T. K., \& Yip, L. S. (2008). The moderator effect of monetary sales promotion on the relationship between brand trust and purchase behaviour. Journal of Brand Management. https://doi.org/10.1057/bm.2008.12

19. Kim, J. E., \& Johnson, K. K. P. (2013). The Impact of Moral Emotions on Cause-Related Marketing Campaigns: A Cross-Cultural Examination. Journal of Business Ethics. https://doi.org/10.1007/s10551-012-1233-6

20. Luk, S. T. K., \& Yip, L. S. (2008). The moderator effect of monetary sales promotion on the relationship between brand trust and purchase behaviour. Journal of Brand Management. https://doi.org/10.1057/bm.2008.12

21. Janet Hoek \& Philip Gendall (2008) An Analysis of Consumers' Responses to Cause Related Marketing, vol 2(1) 283-297

22. Langen, N., Grebitus, C., \& Hartmann, M. (2013). Success factors of cause-related marketing in Germany. Agribusiness, 29(2), 207-227. doi:10.1002/agr.21331

23. Laurenţiu, D. A., Georgiana F.G., Mihai, R. ( 2011), Cause Related Marketing -Part of Corporate Social Responsibility and its Influence upon Consumer's Attitude, Amfiteatru Economic, Vol. XII, No. 29, pp. 72-83.

24. Lavack, A.M., \& Kropp, F. (2003). A cross-cultural comparison of consumer attitudes toward cause-related marketing. Social Marketing Quarterly, 9 (2), 3-16. DOI: 10.1080/15245000309103

25. Mohr, L.A., Webb, D.J. and Harris, K.E. (2001), "Do consumers expect companies to be socially responsible? The impact of corporate social responsibility on buying behavior", The Journal of Consumer Affairs, Vol. 35 No. 1, pp. 47-72.

26. Pringle, H., \& Thompson, M. (1999). Brand Spirit: How cause-related marketing builds a brand. Chichester: John Wiley.

27. Ross, J.K., Patterson, L.T. and Stutts, M.A. (1992), "Consumer perceptions of organizations that use cause-related marketing," Journal of the Academy of Marketing Science, Vol. 20 No. 1, pp. 93-7.

28. Ross, J.K., Stutts, M.A. and Patterson, L.T. (1990-1991), "Tactical considerations for the effectiveness of cause-related marketing," The Journal of Applied Business Research, Vol. 7 No. 2, pp. 58-65. 
29. Sen, S. and Bhattacharya, C.B. (2001), "Does doing good always lead to doing better? Consumer reactions to corporate social responsibility", Journal of Marketing Research, Vol. 38, May, pp. 225-43.

30. Shabbir, S., Kaufmann, H. R., Ahmad, I., \& Qureshi, I. M. (2010) Cause-related marketing campaigns and consumer purchase intentions: The mediating role of brand awareness and corporate image. African Journal of Business Management, 4(6), 1229.

31. Shell, A. (1989), "Cause-related marketing: big risks, big potential," Public Relations Journal, Vol. 45 No. 7, pp. 8-13.

32. Spears, N., \& Singh, S. N. (2004). Measuring attitude toward the brand and purchase intentions. Journal of Current Issues \& Research in Advertising, 26(2), 53-66.

33. Varadarajan, P. R., \& Menon, A. (1988). Cause-related marketing: A coalignment of marketing strategy and corporate philanthropy. Journal of Marketing, 52 (3), 58-74.

34. Webb, D.J., \& Mohr, L.A. (1998). A typology of consumer responses to cause-related marketing: From skeptics to socially concerned. Journal of Public Policy \& Marketing, 17 (2), 226-238

35. Yanli, C., Trent, E.S., Sullivan, P.M., \& Matiru, G.N. (2003). Cause-related marketing: How Generation Y responds. International Journal of Retail and Distribution Management, 31 (6), 310-320.

36. Youn, S., \& Kim, H. (2008). Antecedents of consumer attitude toward cause-related marketing. Journal of Advertising Research, 48(1), 123-137.

\section{AUTHORS PROFILE}

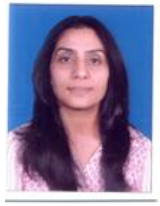

Dr. Suchita Jha, is a MBA (Marketing) and holds a Ph.D. degree in Marketing. She has worked with Aptech, Intel Teach \& KhimjiRamdas group in India \& Muscat, Oman as Marketing professional. She worked with colleges across Oman, UAE \& India with reputed colleges. She is also part of various start up consultancy on Marketing. Her research interests include Services marketing, Consumer behaviour etc. She is a reviewer of some International Journals and has published research papers in International Journals. Email: suchita.jha@siib..ac.in Phone: O: +91-20-22934314-447 M: +919004344974 